\title{
Ecological Implications from a Molecular Analysis of Phytoplasmas Involved in an Aster Yellows Epidemic in Various Crops in Texas
}

\author{
I.-M. Lee, M. Martini, K. D. Bottner, R. A. Dane, M. C. Black, and N. Troxclair
}

First, second, third, and fourth authors: U.S. Department of Agriculture-Agricultural Research Service, Molecular Plant Pathology Laboratory, Beltsville, MD 20705; and fifth and sixth authors: Texas A\&M University Research and Extension Center, Uvalde 78802. Current address of M. Martini: Department of Biologia Applicata alla Difesa della Piante, University of Udine, 33100 Udine, Italy. Accepted for publication 23 May 2003.

\begin{abstract}
Lee, I.-M., Martini, M., Bottner, K. D., Dane, R. A., Black, M. C., and Troxclair, N. 2003. Ecological implications from a molecular analysis of phytoplasmas involved in an aster yellows epidemic in various crops in Texas. Phytopathology 93:1368-1377.

In the spring of 2000, an aster yellows (AY) epidemic occurred in carrot crops in the Winter Garden region of southwestern Texas. A survey revealed that vegetable crops, including cabbage, onion, parsley, and dill, and some weeds also were infected by AY phytoplasmas. Nested polymerase chain reaction (PCR) and restriction fragment length polymorphism analysis of PCR-amplified phytoplasma 16S rDNA were employed for the detection and identification of phytoplasmas associated with these crops and weeds. Phytoplasmas belonging to two subgroups, $16 \mathrm{SrI}-\mathrm{A}$ and $16 \mathrm{SrI}-\mathrm{B}$, in the AY group (16SrI), were predominantly detected in infected plants. Carrot, parsley, and dill were infected with both subgroups. Onion and three species of weeds (prickly lettuce, lazy daisy, and false ragweed) were predominantly or exclusively infected by subgroup 16SrI-A phytoplasma strains, while cabbage was infected by subgroup 16SrI-B phytoplasmas. Both types of phytoplasmas were de-

tected in three leafhopper species, Macrosteles fascifrons, Scaphytopius irroratus, and Ceratagallia abrupta, commonly present in this region during the period of the epidemic. Mixed infections were very common in individual carrot, parsley, and dill plants and in individual leafhoppers. Sequence and phylogenetic analyses of $16 \mathrm{~S}$ rDNA and ribosomal protein (rp) gene sequences indicated that phytoplasma strains within subgroup 16SrI-A or subgroup 16SrI-B, detected in various plant species and putative insect vectors, were highly homogeneous. However, based on rp sequences, two rpI subgroups were identified within the subgroup 16SrIA strain cluster. The majority of subgroup 16SrI-A phytoplasma strains were classified as rp subgroup rpI-A, but phytoplasma strains detected in one onion sample and two leafhoppers (M. fascifrons and C. abrupta) were different and classified as a new rp subgroup, rpI-N. The degree of genetic homogeneity of the phytoplasmas involved in the epidemic suggested that the phytoplasmas came from the same pool and that all three leafhopper species may have been involved in the epidemic. The different phytoplasma population profiles present in various crops may be attributed to the ecological constraints as a result of the vectorphytoplasma-plant three-way interaction.
\end{abstract}

Aster yellows (AY) is the most widespread plant disease among those known to be caused by phytoplasmas $(7,12,14,19-22)$. AY phytoplasmas are associated with diseases in more than 100 plant species worldwide, predominantly in herbaceous dicot plants (20). In North America, AY diseases are attributed primarily to phytoplasma strains belonging to subgroups 16SrI-A (termed Eastern AY phytoplasma) and 16SrI-B (termed California AY or Western AY phytoplasma) in the AY group $(16 \mathrm{SrI})(8,12,13)$. Both 16SrI-A and 16SrI-B phytoplasmas are transmitted by a variety of polyphagous leafhopper species and have a wide range of plant hosts (23). Although each has its own host specificity, the two subgroup phytoplasma strains share some common insect and plant hosts (23). Thus, the vector-phytoplasma-plant relationships that lead to infection with AY in potential plant hosts are complicated. Because of the probability of both plant and insect hosts being infected by both types of phytoplasma strains, the common vectors and host plants may become infected by phytoplasma strains of both subgroups. Due to the differing degrees of susceptibility to infection by these two subgroup phytoplasmas, these common host plants or insect vectors may sustain different population pro-

Corresponding author: I.-M. Lee; E-mail address: leeim@ba.ars.usda.gov

* The $e$-Xtra logo stands for "electronic extra" and indicates that the online version contains supplemental material not included in the print edition. Figure 6 is in color online.

Publication no. P-2003-0902-01R

This article is in the public domain and not copyrightable. It may be freely reprinted with customary crediting of the source. The American Phytopathological Society, 2003. files of mixed phytoplasmas. Minor or cryptic phytoplasma strains in one host may predominate in another host (16). However, this hypothetical mode of different phytoplasma population profiles as a result of ecological constraints never has been demonstrated in nature.

In 2000, an AY epidemic occurred in carrot (Daucus carrota) in southwestern Texas. The disease spread throughout the region and caused severe loss in carrot production. A preliminary survey revealed that several vegetable crops, including cabbage (Brassica oleracea) (10), onion (Allium cepa) (9), dill (Anethum graveolens), and parsley (Petroselinum crispum), and some biennial weeds in this region also were infected by AY phytoplasmas. A survey on potential insect vectors indicated that at least three leafhopper species might have been involved in the AY epidemic. The epidemic provided an opportunity for us to study the ecological aspects of AY phytoplasmas associated with various vegetable crops, weeds, and potential insect vectors. The objectives of the present work were to elucidate components of the AY epidemic in Texas that included identification of the phytoplasma strains involved and an analysis of strain populations infecting different vegetable, weed, and candidate vector insect species, and propose a hypothetical ecological model illustrating the three-way interaction among plant hosts, phytoplasmas, and insect vectors involved in the AY epidemic. Our findings revealed that at least three distinct types of phytoplasmas belonging to subgroups 16SrI-A (containing ribosomal protein [rp] subgroup rpI-A and a new subgroup rpI-N) and 16SrI-B (containing rpI-B) were involved in the epidemics. Mixed infections were common in plants as well as in the potential vectors but the population profiles of mixed 
phytoplasmas varied with individual crops as well as individual plants. A preliminary report of part of this work has been published (11).

\section{MATERIALS AND METHODS}

Source of infected plants and leafhoppers. AY-infected carrot (planted from November through January) was collected from three separate fields, infected cabbage (planted in September) and onion (planted in October) from the fields next to a carrot field heavily infected with AY, and weeds (false ragweed, Parthenium hysterophorus L.; prickly lettuce, Sonchus asper (L) Hill; and lazy daisy, Aphanostephus skirrhobasis var. kidderi (Blake) B.L.) from the cabbage field in April and May 2000 in the Winter Garden region in southwestern Texas. Leafhoppers were collected by netsweeping from the same carrot fields where infected plant samples were collected. Leafhoppers were preserved in $70 \%$ alcohol before use for DNA extractions.

Polymerase chain reaction and restriction fragment length polymorphism analysis. Total nucleic acid of plant samples was extracted using $0.5 \mathrm{~g}$ of midvein or petiole tissue according to a modified procedure using the DNeasy Plant Mini Kit (Qiagen, Valencia, CA) as previously described by Green et al. (3). For leafhoppers, total nucleic acid was extracted from an individual leafhopper by grinding for $30 \mathrm{~s}$ at speed 4.5 in a Savant Fast Prep Machine (Q-Biogene, Carlsbad, CA) with $0.5 \mathrm{ml}$ of cetyltrimethylammonium bromide extraction buffer, sphere, and garnet in a 2-ml microfuge tube. The extract was transferred to a clean 2-ml microfuge tube and then followed the modified method described above. A nested polymerase chain reaction (PCR) using primer pair P1/P7 $(2,21)$ in the first amplification followed by $\mathrm{R} 16 \mathrm{~F} 2 \mathrm{n} / \mathrm{R} 16 \mathrm{R} 2$ in the second amplification was performed to detect phytoplasmas in infected plants and leafhoppers $(4,17)$. A negative control devoid of DNA templates in the reaction mix was included in all the PCR assays. For PCR amplification, 38 cycles were conducted in an automated thermal cycler (MJ Research DNA Thermal Cycler PTC-200) with AmpliTaq Gold polymerase. PCR was performed in mixtures containing $1 \mu \mathrm{l}$ of undiluted DNA preparation, $200 \mu \mathrm{M}$ each $\mathrm{dNTP}$, and $0.4 \mu \mathrm{M}$ each primer. The following conditions were used: denaturation at $94^{\circ} \mathrm{C}$ for $1 \mathrm{~min}$ (11 $\mathrm{min}$ for the first cycle), annealing for $2 \mathrm{~min}$ at $55^{\circ} \mathrm{C}$, and primer extension for $3 \mathrm{~min}\left(7 \mathrm{~min}\right.$ in the final cycle) at $72^{\circ} \mathrm{C}$. Diluted (1:30) PCR product ( $1 \mu \mathrm{l})$ from the first amplification was used as the template in the nested PCR. The PCR products $(5 \mu \mathrm{l})$ were electrophoresed through a $1 \%$ agarose gel, stained in ethidium bromide, and visualized with a UV transillluminator. Restriction fragment length polymorphism (RFLP) analysis of nested PCR products (1.2-kb 16S rDNA fragments) was used for identification of the putative phytoplasmas detected (17). The PCR products (6 to $8 \mu \mathrm{l})$ were digested singly with each of the restriction enzymes (MseI, HhaI, and BfaI) which were selected for differentiation among phytoplasma groups and subgroups in the AY group (16SrI). A nested PCR using primer pair rpF1/rpR1 (18) followed by $\operatorname{rp}(\mathrm{I}) \mathrm{F} 1 \mathrm{~A} / \mathrm{rp}(\mathrm{I}) \mathrm{R} 1 \mathrm{~A}$ (5'-TTTTCCCCTACACGTACTTA-3' $/ 5^{\prime}$ GTTCTTTTTGGCATTAACAT- $3^{\prime}$ ) was performed to amplify a segment of the rp operon $(\approx 1.2 \mathrm{~kb})$, which included the $3^{\prime}$ end of the $s 19$ gene and the complete $l 22$ and $s 3$ genes, from representative samples from various crops, weeds, and insect vectors. PCR conditions were the same as described previously except the annealing temperature was changed to $50^{\circ} \mathrm{C}$ (5). PCR products of rp sequences were digested with $M s e I$ and Tsp509I. The restriction products then were separated by electrophoresis through a $5 \%$ ( $12 \%$ for rp products) polyacrylamide gel for $1 \mathrm{~h}$ at $150 \mathrm{~V}$ ( $2 \mathrm{~h}$ for $12 \%$ gel), stained in ethidium bromide, and visualized with a UV transilluminator.

Detection of mixed infections. In this study, the term mixed infection refers to an individual plant or insect being infected with more than one phytoplasma strain. Phytoplasmas belonging to subgroup 16SrI-A and 16SrI-B appeared to be involved in the AY epidemic. It was expected that individual plants or insect vectors could be infected with one or both subgroups. To improve the sensitivity of detection for the phytoplasma strain present in low titer in individual plants or insect vectors that were dually infected by both subgroups, we designed rp subgroup-specific primers: rp(I-A)F1/rp(I-A)R1, 5'-CAAGAGCTAAAGGTTCTGGC-3'/5' GAGGGCGCCTGTTAGGGTTA-3' for detection of subgroup 16SrI-A; and rp(I-B)F1/rp(I-B)R2, 5' - AAGAGCTAAAGGTTCTGGT-3'/5'-GAGGGCGTCTGTTAGGAGTG-3' for detection of subgroup 16SrI-B. A nested PCR using a generic primer pair $\mathrm{rpF} 1 /$ rpR1 followed by group 16SrI-specific rp primer pair $\mathrm{rp}(\mathrm{I}) \mathrm{F} 1 \mathrm{~A} /$ $\mathrm{rp}(\mathrm{I}) \mathrm{R} 1 \mathrm{~A}$ or using $\mathrm{rpF} 1 / \mathrm{rpR} 1$ followed separately by rp subgroupspecific primer pair $\mathrm{rp}(\mathrm{I}-\mathrm{A}) \mathrm{F} 1 / \mathrm{rp}(\mathrm{I}-\mathrm{A}) \mathrm{R} 1$ and $\mathrm{rp}(\mathrm{I}-\mathrm{B}) \mathrm{F} 1 / \mathrm{rp}(\mathrm{I}-\mathrm{B}) \mathrm{R} 2$ was performed. PCR conditions were the same as described earlier except for annealing temperatures. The annealing temperature for the first amplification using primer pair $\mathrm{rpF} 1 / \mathrm{rpR} 1$ was $50^{\circ} \mathrm{C}$. The annealing temperatures for nested PCR were $55^{\circ} \mathrm{C}$ for $\mathrm{rp}(\mathrm{I}) \mathrm{F} 1 \mathrm{~A} / \mathrm{rp}(\mathrm{I}) \mathrm{RIA}, 64^{\circ} \mathrm{C}$ for $\mathrm{rp}(\mathrm{I}-\mathrm{A}) \mathrm{F} 1 / \mathrm{rp}(\mathrm{I}-\mathrm{A}) \mathrm{R} 1$, and $60^{\circ} \mathrm{C}$ for $\mathrm{rp}(\mathrm{I}-\mathrm{B}) \mathrm{F} 1 / \mathrm{rp}(\mathrm{I}-\mathrm{B}) \mathrm{R} 2$. The PCR products were analyzed as described earlier. The expected sizes of rp PCR products were $1.2 \mathrm{~kb}$ with primer pair $\operatorname{rp}(\mathrm{I}) \mathrm{F} 1 \mathrm{~A} / \mathrm{rp}(\mathrm{I}) \mathrm{R} 1 \mathrm{~A}$ and $0.8 \mathrm{~kb}$ with both subgroup-specific rp primer pairs. Rp subgroup identifications were

TABLE 1. GenBank accession numbers and subgroup affiliations of aster yellows phytoplasma strains from Texas and of reference taxa

\begin{tabular}{|c|c|c|c|c|}
\hline \multirow[b]{2}{*}{ Strain } & \multicolumn{2}{|c|}{$\begin{array}{l}\text { Subgroup } \\
\text { affiliation }\end{array}$} & \multirow[b]{2}{*}{ 16S rRNA gene } & \multirow[b]{2}{*}{ rp genes ${ }^{\mathrm{a}}$} \\
\hline & $16 \mathrm{SrI}$ & $\mathrm{rpI}$ & & \\
\hline Btsv2CarD1 & $\mathrm{A}$ & A & AY180926 & AY183690 \\
\hline Btsv2CarD3 & $\mathrm{B}$ & $\mathrm{B}$ & AY180945 & AY183710 \\
\hline Btsv2CarD4 & A & A & AY180933 & AT183691 \\
\hline Btsv2CarD5 & A & $\mathrm{A}$ & AY180934 & AY183692 \\
\hline Btsv4CarD6 & A & $\mathrm{A}$ & AY180936 & AY183694 \\
\hline Btsv1CarH4 & A & A & N/A & AY183687 \\
\hline Btsv1CarH10 & B & B & N/A & AY183720 \\
\hline Btsv1CarH11 & $\mathrm{B}$ & B & N/A & AY183709 \\
\hline CabD3 & $\mathrm{B}$ & B & AY180947 & AY183717 \\
\hline CabD4 & $\mathrm{B}$ & B & AY180932 & N/A \\
\hline DillD2 & $\mathrm{B}$ & B & AY180953 & AY183706 \\
\hline DillH2 & A & A & AY180928 & AY183697 \\
\hline OnionD1 & A & $\mathrm{N}$ & AY180948 & AY183685 \\
\hline OnionD2 & A & A & AY180931 & AY183699 \\
\hline OnionD7 & $\mathrm{B}$ & $\mathrm{B}$ & N/A & AY183718 \\
\hline ParsD1 & $\mathrm{B}$ & B & AY180954 & AY183719 \\
\hline ParsD3 & A & A & AY180940 & AY 183700 \\
\hline ParsD4 & $\mathrm{B}$ & B & AY180946 & AY183707 \\
\hline ParsH1 & $\mathrm{A}$ & A & N/A & AY183701 \\
\hline PLD1 & A & A & AY180941 & AY183702 \\
\hline PLD2 & A & A & AY180929 & AY183703 \\
\hline LDD1 & A & A & AY180939 & AY183698 \\
\hline RgwdD1 & A & A & AY180930 & AY183704 \\
\hline RgwdD2 & A & A & AY180942 & AY183705 \\
\hline Btsv2M.f.12 & B & $\mathrm{B}$ & AY180951 & AY183711 \\
\hline Btsv4M.f.6 & A & $\mathrm{N}$ & AY180937 & AY183684 \\
\hline Btsv2S.i.5 & B & $\mathrm{B}$ & AY180927 & AY183712 \\
\hline Btsv2S.i.9 & $\mathrm{B}$ & B & AY180943 & AY183713 \\
\hline Btsv4S.i.1 & $\mathrm{B}$ & B & AY180952 & AY183715 \\
\hline Btsv4S.i.4 & A & A & AY180938 & AY183695 \\
\hline Btsv2C.a.13 & A & A & AY180925 & AY183688 \\
\hline Btsv2C.a.17 & B & $\mathrm{B}$ & AY180944 & AY183716 \\
\hline Btsv2C.a.28a & A & A & N/A & AY183689 \\
\hline Btsv2C.a.28b & $\mathrm{B}$ & $\mathrm{B}$ & AY180949 & N/A \\
\hline Btsv4C.a.2a & A & $\mathrm{N}$ & N/A & AY183683 \\
\hline Btsv4C.a.2b & $\mathrm{B}$ & B & AY180950 & N/A \\
\hline Btsv4C.a.9 & $\mathrm{B}$ & B & N/A & AY183714 \\
\hline Btsv4C.a.21 & A & A & AY180935 & AY183693 \\
\hline AV2192 & $\mathrm{L}$ & B & AY180957 & AY 183708 \\
\hline $\mathrm{BB}$ & A & A & AY180955 & AY183686 \\
\hline Chry & $\mathrm{A}$ & $\mathrm{A}$ & AY180956 & AY183696 \\
\hline MIAY & B & B & M30790 & M74770 \\
\hline Acholeplasma laidlawii & N/A & N/A & M23932 & M74771 \\
\hline
\end{tabular}

a Ribosomal protein genes. 
confirmed by RFLP analyses of nested PCR products with the restriction enzyme Tsp509I for $\operatorname{rp}(\mathrm{I}-\mathrm{A}) \mathrm{F} 1 / \mathrm{rp}(\mathrm{I}-\mathrm{A}) \mathrm{R} 1$ and $\mathrm{rp}(\mathrm{I}-\mathrm{B}) \mathrm{F} 1 /$ $\operatorname{rp}(\mathrm{I}-\mathrm{B}) \mathrm{R} 2$ products (17). The digested products were electrophoresed through a $12 \%$ polyacrylamide gel.

Sequencing and analysis of rRNA and ribosomal protein gene sequences. P1/P7 PCR products were re-amplified with a nested primer pair, P1A/P7A (P1A: 5'-AACGCTGGCGGCGCGCCTAATAC-3' and P7A: 5'-CCTTCATCGGCTCTTAGTGC-3').

P1A/P7A PCR products $(\approx 1.8 \mathrm{~kb})$, which cover $16 \mathrm{~S}$ rDNA, $16 \mathrm{~S}-23 \mathrm{~S}$ intergenic spacer region, and a portion of the $23 \mathrm{~S}$ rDNA at the $3^{\prime}$ end, were cloned in Escherichia coli using TOPO-TA Cloning Kit (Invitrogen, Carlsbad, CA) according to the manu- facturer's instructions. The 1.2-kb rp fragments (rpF1A-rpR1A PCR products) were cloned in E. coli as described previously. Sequencing was performed with an automated DNA sequencer (ABI 377XL; Center for Agricultural Biotechnology, University of Maryland, College Park). Sequences were submitted to GenBank and accession numbers are presented in Table 1. Nearly full-length sequences $(1.5 \mathrm{~kb})$ of $16 \mathrm{~S}$ rDNA or rp gene sequences $(1.2 \mathrm{~kb})$ from representative phytoplasma strains detected in each crop and putative insect vector were aligned separately by using CLUSTAL, version 5, using DNASTAR's Laser Gene software (DNASTAR, Madison, WI). Cladistic analyses were performed with the computer program PAUP (phylogenetic analysis using parsimony),
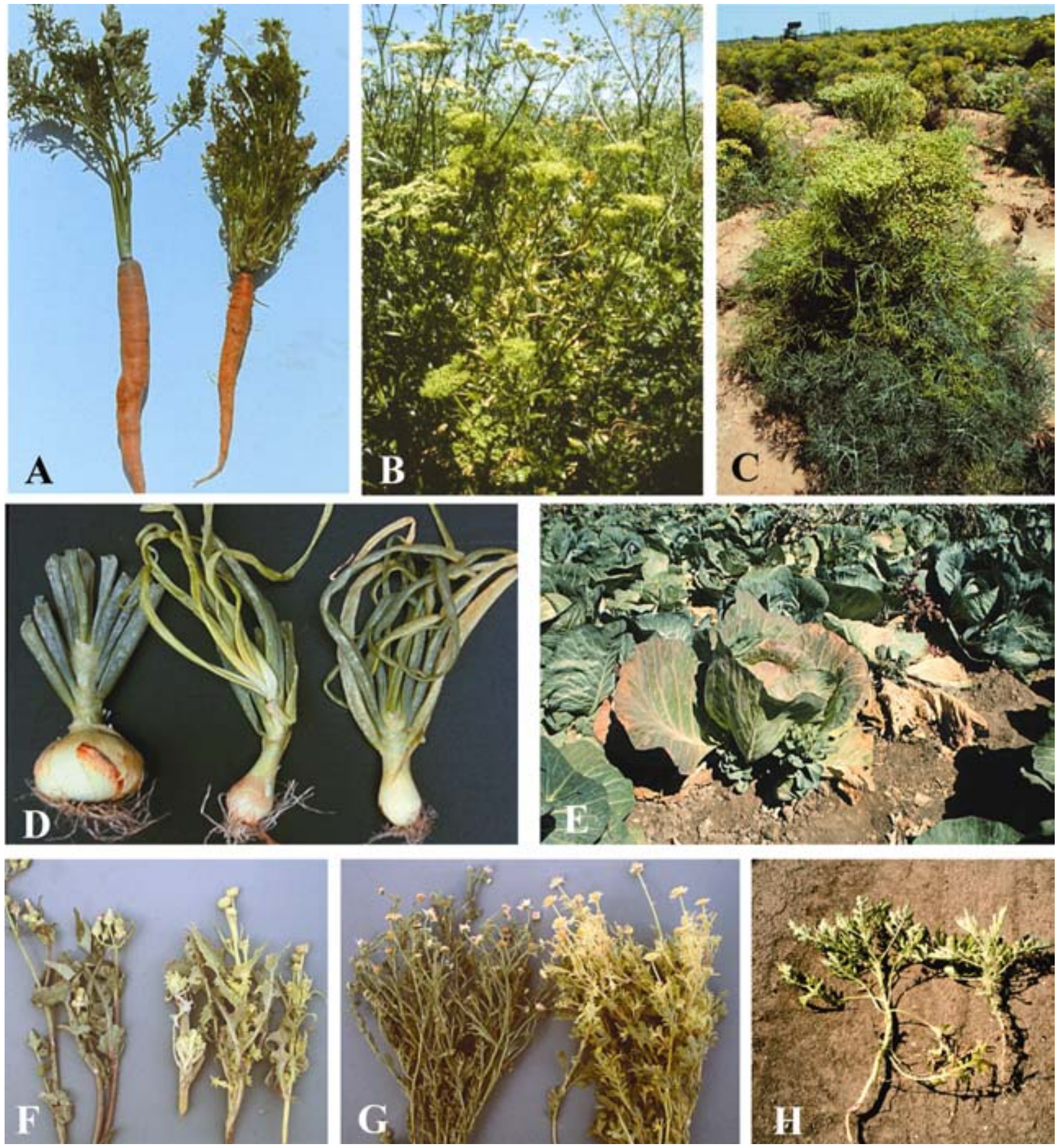

Fig. 1. A, Apparently healthy carrot plant (left) and infected (right) carrot with symptoms showing extensive shoot proliferation. B, Aster yellows (AY)-infected parsley (front) showing virescence and phyllody of flowers and yellowing of leaves. C, AY-infected dill showing virescence and phyllody of flowers and abnormal elongation of the inflorescence. D, Apparently healthy (left) and two AY-infected onion plants showing shoot proliferation and yellowing of shoots and stunting of plants. E, AY-infected cabbage plant showing purple discoloration of leaves and sprouting at the basal stem. F, Apparently healthy (left) and AYinfected (right) prickly lettuce shoots showing shoot proliferation, virescence of flowers, and yellowing of new shoots. G, Apparently healthy (left) and AYinfected (right) lazy daisy showing proliferation and yellowing of new shoots. H, Apparently healthy (left) and AY-infected false ragweed (right) showing proliferation and yellowing of new shoots. 
version 4.0 written by D. L. Swofford (University of Illinois), on a Power Mac G4. Uninformative characters were excluded from analyses. A phylogenetic tree was constructed by using the heuristic bisection and reconnection branch-swapping algorithm to find the optimal phylogenetic tree or trees. Acholeplasma laidlawii was selected as the outgroup to root the tree (17). Bootstrapping (1,000 replications) was performed to estimate the stability and support for the inferred clades. Reference phytoplasma strains included in the phylogenetic analysis were 16SrI-A, tomato big bud and chrysanthemum yellows; and 16SrI-B, AY (AV2192).

\section{RESULTS}

AY-infected crops and weeds and their symptoms. Five vegetable crops and three weeds were infected by AY phytoplasmas in the epidemic. Typical AY symptoms in carrot first were observed in late January and early February 2000 in several fields in Batesville, and the disease spread rapidly throughout the carrot production areas. Infection ranged from 50 to $100 \%$ among the four carrot fields investigated. The symptoms included purple discoloration of leaves (early symptoms), excessive shoot proliferation (Fig. 1A), and abnormal floral formation (virescence and phyllody). The infected plants often produced stunted, hairy, tapered roots. Cabbage crops planted adjacent to affected carrot fields exhibited previously unobserved symptoms characteristic of phytoplasmal infection. Approximately $5 \%$ of cabbage plants showed symptoms, including purple discoloration in leaf veins and at the outer edges of leaves on cabbage heads. Proliferation of sprouts occurred at the base of the stem and between leaf layers, and sprouts sometimes continued to proliferate along extended stems (Fig. 1E). In the same cabbage field, three kinds of weeds, prickly lettuce (Fig. 1F), lazy daisy (Fig. 1G), and false ragweed (Fig. 1H), exhibited AY symptoms, with stunted leaves, shortened internodes, abnormal floral structures, and general chlorosis of plants. Moderate infection was found in one onion field (in Uvalde) located in the vicinity of the carrot fields. Infected onion showed moderate shoot proliferation with light yellowish discoloration on leaves and severe stunting of the plants (Fig. 1D). The bulbs of infected plants were greatly reduced in size. Another two vegetable crops, parsley and dill, which grew in fields $\approx 50$ miles from Batesville and Uvalde, also were infected with AY phytoplasmas. Infected plants of both crops exhibited virescence and phyllody symptoms.

Identification of potential vectors. Three leafhopper species predominant in this region were collected and sent to Stuart $\mathrm{H}$.
McKamey (United States Department of Agriculture-Agricultural Research Service Systematic Entomology Laboratory, National Museum of Natural History, Smithsonian Institution, Washington, DC) for identification. The three species identified were Macrosteles fascifrons, Scaphytopius irroratus, and Ceratagallia (Aceratagallia) abrupta.

Nested PCR, RFLP analyses, and taxonomic affiliations of phytoplasmas. Nested PCR assays were performed using primer pair P1/P7 followed by R16F2n/R16R2. Out of 38 carrot samples, including asymptomatic ones, 35 were positive for phytoplasmas; 5 out of 6 cabbage samples were positive; 6 out of 10 symptomatic onion samples were positive; 5 out of 6 , including 2 asymptomatic, parsley samples were positive; 3 out of 4 dill, including 1 asymptomatic, samples were positive; 1 symptomatic lazy daisy sample was positive; 3 out of 3 prickly lettuce, including 1 asymptomatic, samples were positive; and 3 symptomatic false ragweed samples were positive. For insect vectors, 8 out of $30 \mathrm{M}$. fascifrons from carrot fields were positive; 10 out of $16 \mathrm{~S}$. irroratus were positive; and 24 out of $66 C$. abrupta were positive. All negative controls devoid of DNA template were negative. A summary of the results is presented in Table 2. Based on collective RFLP patterns (Fig. 2A and B) analyzed with restriction enzymes MseI (data not shown), HhaI, and BfaI, phytoplasma 16Sr group and subgroup affiliations were designated to phytoplasmas detected in various plant and insect sources (Table 2). RFLP patterns of R16F2n/R16R2-nested PCR products (1.2-kb fragment of $16 \mathrm{~S}$ rDNA) from representative phytoplasma strains detected in each crop, weed, and insect vector are shown in Figure $2 \mathrm{~A}$ and $\mathrm{B}$. RFLP patterns of amplified rp operon products $(\approx 1.2 \mathrm{~kb})$ from representative phytoplasma strains are shown in Figure $2 \mathrm{C}$. Based on analyses of $16 \mathrm{~S}$ rDNA sequences (Fig. 2A and B), two collective RFLP patterns characteristic of 16SrI-A and 16SrI-B phytoplasma strains, respectively, were identified: 16SrI-A strains included samples PLD1, OnionD1, ParsD3, LDD1, RgwdD1, Btsv2C.a13, Btsv4C.a21, Btsv2C.a28, Btsv4M.f6, Btsv4S.i4, and Btsv4S.i5.; 16SrI-B strains included samples Btsv2CarD3, CabD3, DillD2, ParsD4, Btsv2C.a17, Btsv2M.f12, and Btsv4S.i1. In contrast, three RFLP patterns were identified based on rp gene sequences (Fig. 2C): two were identical to previously reported rpI-A (previously termed 16SrI-A[rp-A]) and rpI-B (previously termed $16 \mathrm{SrI}-\mathrm{B}[\mathrm{rp}-\mathrm{B}]$ ) patterns (17), and one (designated as rpIN) was new. RpI-A strains included samples Btsv4CarD6, LDD1, RgwdD1, OnionD4, PLD1, Btsv4S.i4, and Btsv CarD1; rpI-B strains included samples Btsv2S.i5, Btsv2S.i9; and Btsv2CarD3; and rpI-N included samples OnionD1 and Btsv4C.a2. Phyto-

TABLE 2. Summary of polymerase chain reaction (PCR) detection using 16S rDNA primers and identification of phytoplasmas detected from various crops, weeds, and insects involved in the aster yellows epidemic in southwestern Texas

\begin{tabular}{|c|c|c|c|c|c|c|c|c|}
\hline \multirow[b]{2}{*}{ Plants and insects } & \multirow[b]{2}{*}{ Location } & \multirow[b]{2}{*}{ Date of collection } & \multicolumn{2}{|c|}{ PCR positive $^{\mathrm{a}}$} & \multirow[b]{2}{*}{ Total positive } & \multicolumn{3}{|c|}{ Phytoplasmas detected ${ }^{b}$} \\
\hline & & & Sympt & Asympt & & $16 \mathrm{SrI}-\mathrm{A}$ & 16SrI-B & $16 \mathrm{SrI}-\mathrm{A}+\mathrm{B}$ \\
\hline \multirow[t]{2}{*}{ Carrot } & Batesville-1 & March 20 & $10 / 10$ & $13 / 14$ & $23 / 24$ & 12 & 9 & 2 \\
\hline & Batesville-2 & April 7 & $6 / 6$ & $\ldots$ & $6 / 6$ & 4 & 2 & $\ldots$ \\
\hline Cabbage & Batesville-3 & April 7 & $4 / 4$ & $1 / 2$ & $5 / 6$ & $\ldots$ & 5 & $\ldots$ \\
\hline Dill & Pearsall-1 & April 8 & $2 / 2$ & $1 / 2$ & $3 / 4$ & 1 & 2 & $\ldots$ \\
\hline Onion & Uvalde-1 & May 15 & $6 / 10$ & $0 / 10$ & $6 / 20^{c}$ & 5 & & $\ldots$ \\
\hline Lazy daisy & Batesville-3 & April 7 & $1 / 1$ & $0 / 1$ & $1 / 2$ & 1 & $\ldots$ & $\ldots$ \\
\hline False ragweed & Batesville-3 & April 7 & $3 / 3$ & $0 / 1$ & $3 / 4$ & 3 & $\ldots$ & $\ldots$ \\
\hline \multirow[t]{2}{*}{ Macrosteles fascifrons } & Batesville-2 & April 7 & $\ldots$ & $\ldots$ & $7 / 24$ & 6 & 1 & $\ldots$ \\
\hline & Batesville-4 & April 7 & $\ldots$ & $\ldots$ & $1 / 6$ & 1 & $\ldots$ & $\ldots$ \\
\hline \multirow[t]{2}{*}{ Scaphytopius irroratus } & Batesville-2 & April 7 & $\ldots$ & $\ldots$ & $6 / 12$ & 3 & 3 & $\ldots$ \\
\hline & Batesville-4 & April 7 & $\ldots$ & $\ldots$ & $4 / 4$ & 1 & 3 & $\ldots$ \\
\hline Ceratagallia abrupta & Batesville-2 & April 7 & $\ldots$ & $\ldots$ & $15 / 36$ & 4 & 10 & 1 \\
\hline
\end{tabular}

${ }^{a}$ Nested PCR was performed using primer pair P1/P7 followed by R16F2n/R16R2. Sympt = symptomatic and Asympt = asymptomatic.

${ }^{\mathrm{b}}$ Subgroup affiliations were based on collective restriction fragment length polymorphism patterns with restrinon enzymes $M s e \mathrm{I}, \mathrm{HhaI}$, and BfaI.

${ }^{c}$ One onion sample, OnionD7, was positive for clover proliferation phytoplasma. 

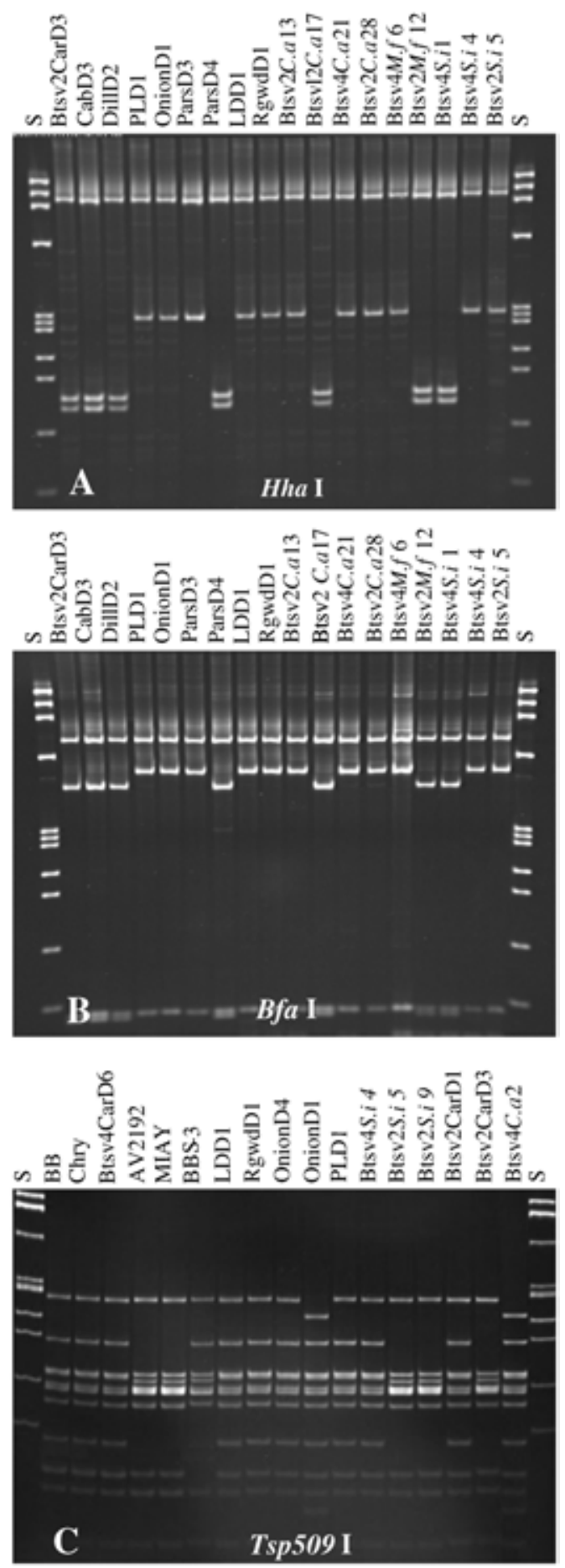

Fig. 2. Restriction fragment length polymorphism (RFLP) analyses of $16 \mathrm{~S}$ rDNAs (R16F2n/R16R2 nested polymerase chain reaction [PCR] products) and ribosomal protein (rp) gene sequences (rp(I)F1A/rp(I)R1A nested PCR products) from vegetable crops: carrot, cabbage, onion, parsley, and dill; weeds: prickly lettuce, lazy daisy, and false ragweed; and insect vectors: Macrosteles fascifrons, Scaphytopius irroratus, and Ceratagallia abrupta. $16 \mathrm{~S}$ rDNA products were digested with $\mathbf{A}, H h a \mathrm{I}, \mathbf{B}, B f a \mathrm{I}$, and $\mathbf{C}$, rp gene sequences with Tsp509I. 16Sr group and subgroup affiliations of phytoplasmas detected in various plant and insect sources were determined based on collective RFLP patterns derived by analyses of $\mathrm{F} 2 \mathrm{n} / \mathrm{R} 2-\mathrm{PCR}$ products with restriction enzymes $H h a \mathrm{I}$ and $B f a \mathrm{I}$. Rp subgroup affiliations were determined by Tsp509I-RFLP analysis of $\mathrm{rp}(\mathrm{I}) \mathrm{F} 1 \mathrm{~A} / \mathrm{R} 1 \mathrm{~A}-\mathrm{PCR}$ products. Reference strains: 16SrI-A (rp-A): BB, Chry; 16SrI-B(rp-B): AV2192, MIAY; 16SrIE(rp-E): BBS-3. Btsv, Batesville; PL, prickly lettuce; Pars, parsley; Car, carrot; Cab, cabbage; Rgwd, false ragweed; LD, lazy daisy; M.f, M. fascifrons; S.i, S. irroratus; C.a, C. abrupta; AY, aster yellows. Lane S, ØX 174 RF1 DNA HaeIII digest, fragment sizes (bp) from top to bottom: 1,353, 1,078, $872,603,310,281,271,234,194,118$, and 72. plasma strains associated with onion yellows (OD1) and two insects, Btsv4C.a.2 (C. abrupta) and Btsv4M.f.6 (M. fascifrons) (data not shown), belonged to this new rp subgroup.

Mixed infection. A summary of the results obtained using generic rp primers $\mathrm{rp}(\mathrm{I}) \mathrm{F} 1 \mathrm{~A} / \mathrm{rp}(\mathrm{I}) \mathrm{R} 1 \mathrm{~A}$ versus subgroup-specific primers is presented in Table 3 . The specific primers permitted a more sensitive detection of the minor phytoplasmas involved in the diseases. Results of PCR using rp primers $\mathrm{rp}(\mathrm{I}-\mathrm{A}) \mathrm{F} 1 / \mathrm{rp}$ (IA)R1 specific to $16 \mathrm{SrI}-\mathrm{A}$ phytoplasmas are shown in Figure $3 \mathrm{~A}$, $\mathrm{B}$, and $\mathrm{E}$ (left); results of PCR using primers $\mathrm{rp}(\mathrm{I}-\mathrm{B}) \mathrm{F} 2 / \mathrm{rp}(\mathrm{I}-\mathrm{B}) \mathrm{R} 2$ specific to 16SrI-B phytoplasmas are shown in Figure 3C, D, and E (right). For carrot, parsley, and two insect species, S. irroratus and $C$. abrupta, which were shown to be equally susceptible to both subgroup 16SrI-A (or rpI-A) and subgroup 16SrI-B (or rpI-B) strains, mixed infections were found to be very common. The mixed infections ranged from 49 to $100 \%$ in the samples tested. In contrast, mixed infections were not detected in some crops (onion and cabbage) and the three weeds, which appear to exhibit differential susceptibility to subgroup 16SrI-A and subgroup 16SrI-B phytoplasmas. The vector $M$. fascifrons appeared to be more susceptible to subgroup16Sr I-A (Table 2). RFLP analyses of the PCR products confirmed the subgroup identification based on PCR assays with rp subgroup-specific primers (Fig. 4). Patterns shown in lanes 2 to 7 represent subgroup rpI-A and lanes 8 to 14 represent subgroup rpI-B.

Genetic variations among phytoplasma strains associated with various crops, weeds, and insect vectors. The genetic variations were evaluated by analyses of sequences from both $16 \mathrm{~S}$ rRNA and two ribosomal protein genes. Sequence variations were evident among subgroup 16SrI-A or 16SrI-B strains associated with various crops, weeds, and putative insect vectors. The variations also were found in strains (within either subgroup 16SrI-A or $16 \mathrm{SrI}-\mathrm{B})$ that were associated with the same crop or the same leafhopper species. Based on $16 \mathrm{~S}$ rDNA sequences, the average sequence homology among subgroup 16SrI-A and 16SrI-B strains were 99.1 and $99.2 \%$, respectively, while the average sequence homology between 18 representative subgroup $16 \mathrm{SrI}-\mathrm{A}$ and 12 subgroup 16 SrI-B strains detected in this study was $98.6 \%$. Based on rp sequences, the average sequence homology among 21 representative strains within subgroup $16 \mathrm{SrI}-\mathrm{A}$ and 14 strains within subgroup 16SrI-B were 99.5 and $99.7 \%$, respectively, while the average sequence homology between subgroup 16SrI-A and subgroup 16SrI-B strains was $97.2 \%$.

Phylogenetic analyses. Phylogenetic analysis of the phytoplasma strains detected from various plant species and from insect vectors resulted in 96 equally parsimonious trees based on $16 \mathrm{~S}$ rRNA gene sequences, which showed random variations of branching patterns. However, each tree resolved two distinct subclades, which correspond to subgroups 16SrI-A and 16SrI-B. One of the best-fitted trees is presented in Figure 5A. In contrast, analysis based on rp gene sequences produced only three trees. Phylogeny based on rp sequences delineated three distinct subclades, which correspond to rp subgroups rpI-A and rpI-B, and a new rp subgroup, rpI-N. One of best-fitted trees is presented in Figure 5B.

\section{DISCUSSION}

AY disease in Texas has occurred sporadically since the first outbreak of AY in the Winter Garden region of Texas was reported in 1944 (6). A major outbreak of AY occurred in 2000 that affected several vegetable crops. Among them, carrot was most severely infected by AY. AY had spread throughout the carrot-growing regions in southwestern Texas. Although AY phytoplasma was assumed to be the cause of the disease, molecular identification of the causal phytoplasmas never had been attempted until this study. The results of a survey in three representative carrot fields, where infections ranged from 50 to near $100 \%$, indicated that phytoplasmas belonging to two subgroups, $16 \mathrm{SrI}-\mathrm{A}$ and $16 \mathrm{SrI}-\mathrm{B}$, in the 
AY phytoplasma group (16SrI) were the cause of AY disease in carrots. Carrot plants were infected singly by strains of subgroup 16SrI-A or 16SrI-B, or dually infected by mixed strains of both subgroups. However, at Batesville (field 3), carrot plants were infected exclusively by subgroup 16 SrI-A phytoplasma strains. Phytoplasma strains belonging to the same two subgroups were found to be associated with other vegetable crops (cabbage, onion, dill, and parsley) and several common biennial weeds (false

TABLE 3. Constituent phytoplasmas present in various crops, weed, and insects involved in the aster yellows epidemic in southwestern Texas as detected by nested polymerase chain reaction (PCR) using generic and ribosomal protein (rp) subgroup-specific primers

\begin{tabular}{|c|c|c|c|c|c|c|c|c|}
\hline \multirow[b]{2}{*}{ Plants and insects } & \multirow[b]{2}{*}{ Field } & \multirow[b]{2}{*}{$\mathrm{rp}(\mathrm{I}) \mathrm{F} 1 \mathrm{~A} / \mathrm{rp}(\mathrm{I}) \mathrm{R} 1 \mathrm{~A}$ positives } & \multicolumn{3}{|c|}{ AluI digestion of $\mathrm{rp}(\mathrm{I}) \mathrm{F} 1 \mathrm{~A} / \mathrm{rp}(\mathrm{I}) \mathrm{R} 1 \mathrm{~A}$} & \multicolumn{3}{|c|}{ PCR positive by subgroup-specific primer } \\
\hline & & & rpI-A & rpI-B & rpI-A+B & rpI-A & rpI-B & rpI-A+B \\
\hline \multirow[t]{2}{*}{ Carrot } & Batesville-1 & $20 / 24$ & $10 / 20$ & $0 / 20$ & $10 / 20$ & $20 / 24$ & $17 / 24$ & $15 / 20$ \\
\hline & Batesville-2 & $5 / 5$ & $4 / 5$ & $1 / 5$ & $0 / 5$ & $3 / 5$ & $2 / 5$ & $1 / 5$ \\
\hline Cabbage & Batesville-3 & $2 / 2$ & $0 / 2$ & $2 / 2$ & $0 / 2$ & $0 / 2$ & $2 / 2$ & $0 / 2$ \\
\hline Dill & Pearsall-1 & $2 / 2$ & $1 / 2$ & $1 / 2$ & $0 / 2$ & $1 / 2$ & $1 / 2$ & $0 / 2$ \\
\hline Onion & Uvalde-1 & $8 / 8$ & $7 / 8$ & $1 / 8$ & $0 / 8$ & $7 / 8$ & $1 / 8$ & $0 / 8$ \\
\hline False ragweed & Batesville-3 & $2 / 2$ & $2 / 2$ & $0 / 2$ & $0 / 2$ & $2 / 2$ & $0 / 2$ & $0 / 2$ \\
\hline \multirow[t]{2}{*}{ Macrosteles fascifrons } & Batesville-2 & $1 / 1$ & $0 / 1$ & $0 / 1$ & $1 / 1$ & $0 / 1$ & $1 / 1$ & $0 / 1$ \\
\hline & Batesville-4 & $1 / 1$ & $0 / 1$ & $0 / 1$ & $1 / 1$ & $1 / 1$ & $0 / 1$ & $0 / 1$ \\
\hline \multirow[t]{2}{*}{ Scaphytopius irroratus } & Batesville-2 & $2 / 2$ & $0 / 2$ & $1 / 2$ & $1 / 2$ & $2 / 2$ & $2 / 2$ & $2 / 2$ \\
\hline & Batesville-4 & $2 / 2$ & $1 / 2$ & $0 / 2$ & $1 / 2$ & $2 / 2$ & $2 / 2$ & $2 / 2$ \\
\hline Ceratagallia abrupta & Batesville-2 & $3 / 3$ & $1 / 3$ & $0 / 3$ & $2 / 3$ & $3 / 3$ & $3 / 3$ & $3 / 3$ \\
\hline
\end{tabular}

$\bar{a}$ Subgroups rpI-A and rpI-B detected with primer pairs rp(I-A)F1/rp(I-A)R1 and rp(I-B)F1/rp(I-B)R2, respectively.

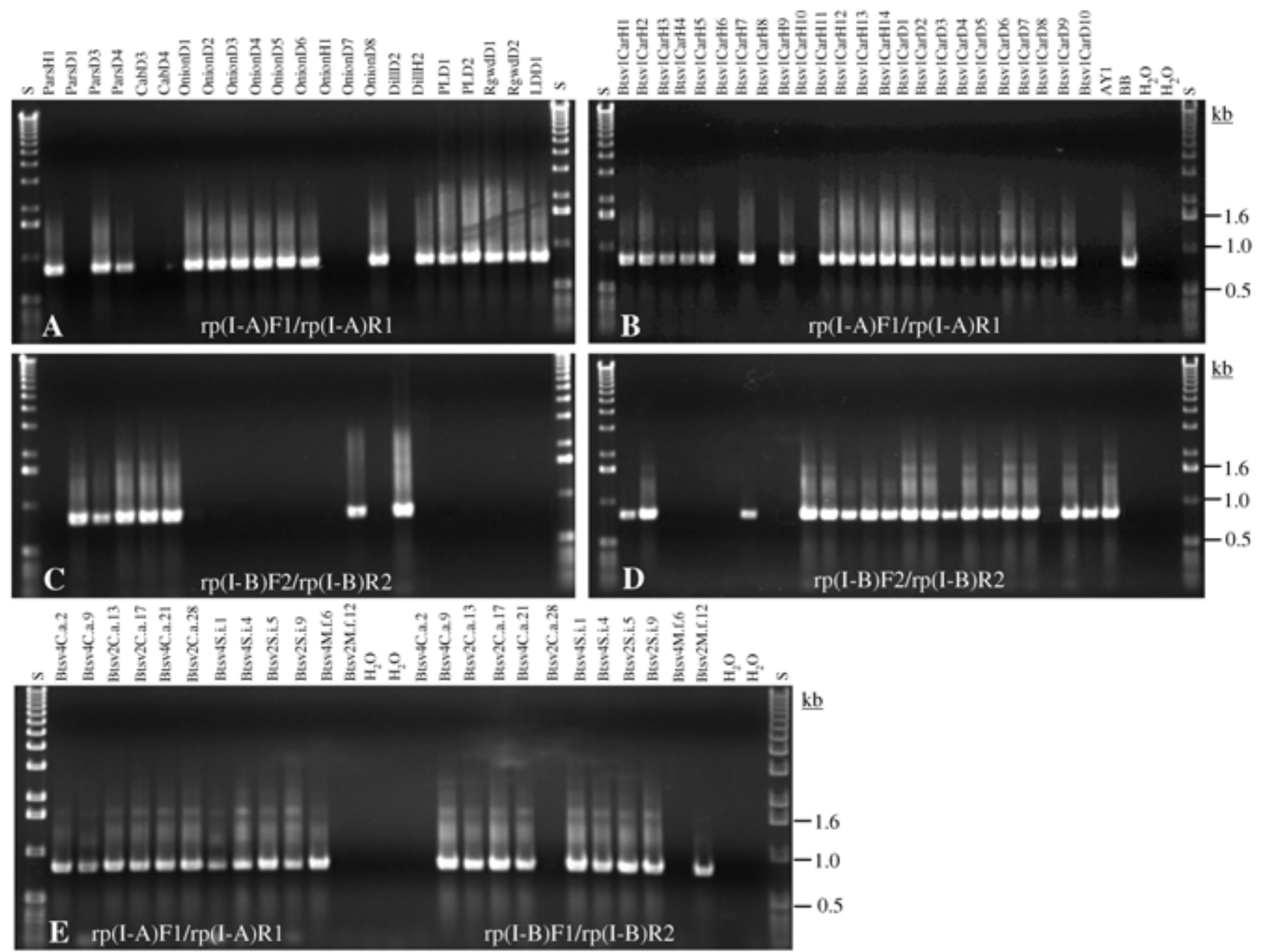

Fig. 3. Mixed infections as indicated by the presence of both 16SrI-A and 16SrI-B specific ribosomal protein (rp) gene sequences (nested polymerase chain reaction [PCR] products with rp subgroup specific primers) from vegetable crops: carrot (Car), cabbage (Cab), onion, parsley (Pars), and dill; from weeds: prickly lettuce (PL), false ragweed (Rgwd), and lazy daisy (LD); and from leafhoppers: Ceratagallia abrupta (C.a.), Scaphytopius irroratus (S.i.), and Macrosteles fascifrons (M.f.). A generic rp primer pair $\mathrm{rpF} 1 / \mathrm{rpR} 1$ was used in the first PCR amplification. In the nested PCR, A, B, and E (left), rp primers rp(IA)F1/rp(I-A)R1 specific to 16SrI-A phytoplasmas and $\mathbf{C}$, D, and $\mathbf{E}$ (right), primers rp(I-B)F2/rp(I-B)R2 specific to 16SrI-B phytoplasmas were used to amplify the nested rp sequences $(0.8 \mathrm{~kb})$. Lane $\mathrm{S}, 1-\mathrm{kb}$ DNA ladder. 
ragweed, prickly lettuce, and lazy daisy) that grow in this region. Although dill and parsley were infected by phytoplasma strains of both subgroups, cabbage, onion, and three biennial weeds were singly infected by strains of either subgroup 16SrI-A or subgroup 16SrI-B. M. fascifrons, S. irroratus, and C. (Aceratagallia) abrupta were the three most predominant leafhoppers in these fields at the time of sampling. Each species carried either subgroup 16SrI-A or subgroup 16SrI-B strains or both strains together, although $M$. fascifrons primarily carried subgroup 16SrI-A phytoplasma strains.

Sequence and phylogenetic analyses of 16S rRNA genes revealed that both subgroup16SrI-A and subgroup 16SrI-B phytoplasmas found in the Winter Garden region consisted of mixed populations of different variants that were randomly distributed in various diseased crops, nearby weeds, and associated leafhoppers. The sequence variations among these variants were random in most cases. There was no evidence that a specific variant of subgroup16SrI-A or 16SrI-B was associated with infected onion, cabbage, or weeds. The homogeneity of the majority of phytoplasma strains within subgroup 16SrI-A or subgroup 16SrI-B was further supported by analysis of rp gene sequences, which are more variable than $16 \mathrm{~S}$ rRNA gene sequences. As expected, based on rp sequences, distinctions between subgroup16SrI-A and subgroup 16SrI-B strains became more obvious (sharing an average of $97.2 \%$ sequence homology), underscoring that they clearly represented two distinct lineages. In addition, a new distinct lineage (rp subgroup rpI-N) within subgroup 16SrI-A was identified in one onion sample (OnionD7) and in two leafhoppers belonging to $M$. fascifrons and $C$. abrupta. However, all other $16 \mathrm{SrI}-\mathrm{A}$ or $16 \mathrm{SrI}-\mathrm{B}$ strain variants identified based on $16 \mathrm{~S}$ rRNA sequences, regardless of host (both plant and insect vector) origins, were more homogenous ( $>99.8 \%$ homology) based on rp gene sequences. The degree of homogeneity among strains in subgroup $16 \mathrm{SrI}-\mathrm{A}$ and subgroup $16 \mathrm{SrI}-\mathrm{B}$ suggests that the

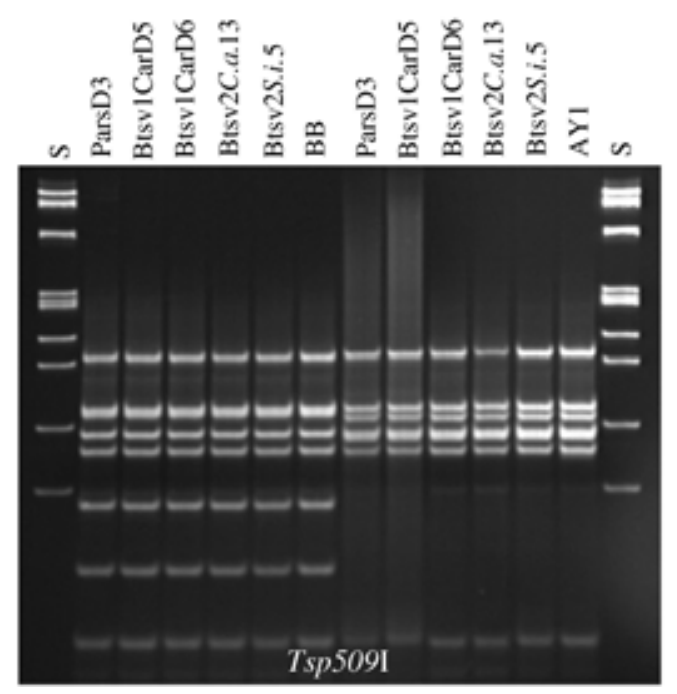

Fig. 4. Restriction fragment length polymorphism patterns of two ribosomal protein (rp) sequences specific to subgroup16SrI-A and subgroup 16SrI-B strains, respectively. The rp gene sequences were nested polymerase chain reaction (PCR) products amplified from individual plants or insect vectors dually infected with both $16 \mathrm{SrI}-\mathrm{A}$ and $16 \mathrm{SrI}-\mathrm{B}$ phytoplasma strains. A generic rp primer pair rpF1/rpR1 was used in the first PCR amplification. In the nested PCR, rp primers $\mathrm{rp}(\mathrm{I}-\mathrm{A}) \mathrm{F} 1 / \mathrm{rp}(\mathrm{I}-\mathrm{A}) \mathrm{R} 1$ specific to $16 \mathrm{SrI}-\mathrm{A}$ phytoplasmas (lanes 2-7) and primers $\mathrm{rp}(\mathrm{I}-\mathrm{B}) \mathrm{F} 2 / \mathrm{rp}(\mathrm{I}-\mathrm{B}) \mathrm{R} 2$ specific to $16 \mathrm{SrI}-\mathrm{B}$ phytoplasmas (lanes 8-14) were used to amplify the nested rp sequences $(0.8 \mathrm{~kb})$ from individual plants and insects with mixed infections. Reference strains: BB, 16SrI-A; AY1, 16SrI-B. Lane S, ØX 174 RF1 DNA Hae III digest, fragment sizes (bp) from top to bottom: 1,353, 1,078, 872, 603, 310, 281, 271, 234, 194, 118, and 72. Pars, parsley; Btsv, Batesville; Car, carrot; C.a., Ceratagallia abrupta; S.i., Scaphytopius irroratus; AY, aster yellows. source of phytoplasma strains that caused diseases in various crops and weeds in the Winter Garden region most likely originated from the same common pools, presumably migratory leafhoppers.

It is very likely that all three leafhoppers investigated in this study contributed to the spread of AY disease in the vegetable crops and weeds. The hypothesis is, in part, supported by the facts that the three leafhopper species are polyphagous; that phytoplasma strains (either belonging to subgroup 16SrI-A or 16SrI-B) detected in carrot, cabbage, dill, parsley, and weeds are remarkably similar based on analyses of $16 \mathrm{~S}$ rRNA and ribosomal protein gene sequences; and that these crops and weeds have are all known hosts of AY phytoplasmas and of the three leafhoppers. Two of the three leafhoppers identified in this study are known to transmit both $16 \mathrm{SrI}-\mathrm{A}$ and $16 \mathrm{SrI}-\mathrm{B}$ phytoplasmas. M. fascifrons is the principal vector that transmits Eastern AY phytoplasma (belonging to subgroup $16 \mathrm{SrI}-\mathrm{A}$ ) in the northeastern region of the United States and in Canada (7), whereas S. irroratus is a principal vector of Western AY phytoplasma (belonging to $16 \mathrm{SrI}-\mathrm{B}$ ) that disseminates primarily in the western coastal regions, the Midwest, and the southern United States (23). C. abrupta, however, has not been reported before to be a vector of AY or any other phytoplasma. Because of its abundance in this region and its capability to carry AY phytoplasma $(\approx 50 \%$ of individual insects tested positive), C. abrupta may play an equally important role in the epidemic.

It is intriguing that, in this outbreak, the vegetables and weeds were infected differentially by either subgroup 16SrI-A or 16SrI-B phytoplasma strains, although two of the three potential vector species carried both subgroup 16SrI-A and subgroup 16SrI-B strains. The availability of vectors in different fields and at different times during the growing season may influence the types of phytoplasma that cause the disease in each plant or each crop. However, the three-way interactions, phytoplasma-vector-host plant (Fig. 6), represent another important determinant (16). Insect feeding preferences of plant hosts and differential susceptibilities of host plants to phytoplasmas will determine the constituents of phytoplasma types in each individual infected plant or in a given crop. Because all three potential vectors carried mixed strains of phytoplasmas, we expected that mixed infections should be common in these crops and in insect vectors. Preliminary PCR or RFLP assays using universal primers detected only a few cases of mixed infections in individual plants and insect vectors. The approach apparently failed to detect the minor phytoplasma in samples where the ratio of primary to minor phytoplasma population was high. To overcome this limitation, we designed rp subgroup-specific primers that allowed selective amplification of minor phytoplasma strains in the mixed infections. As predicted, mixed infections were very common in carrots, parsley, dill, and two of the three insect vectors ( $S$. irroratus and $C$. abrupta). These three crops and the two vector species appear to be near or equally susceptible to infections by both 16 SrI-A and 16SrI-B phytoplasma strains. This is the first case in which mixed infections have involved phytoplasmas of the same group (AY group). $M$. fascifrons was predominantly infected by 16 SrI-A. Mixed infections also can involve phytoplasmas belonging to two or more different groups $(1,15)$. In the present study, one onion was found to be infected by dual phytoplasma strains, a clover proliferation (CP) group-related strain (predominant) mixed with a $16 \mathrm{SrI}-\mathrm{B}$ strain. The CP-related phytoplasma never has been reported associated with onion. The infection may involve another unknown vector. Because of low incidence of the $\mathrm{CP}$ phytoplasma in onion, the unknown vector may be only an occasional feeder. The single infections found in onion (by 16SrI-A phytoplasma stains), cabbage (by 16SrI-B), and three weed species (all infected by $16 \mathrm{SrI}-\mathrm{A})$ were unexpected, because they all grew in the vicinity of carrot fields where the sources of both 16SrI-A and 16SrI-B strains were equally available. Dissemination of phytoplasmas 
depends on insect vectors, which play an active role in the spread of the disease; therefore, we hypothesize that various phytoplasma strains could become isolated or redistributed disproportionally from common pools (insect vectors) into different ecological niches (plant hosts) as a result of phytoplasma-vector-plant host interactions. Without an insect transmission study, it remains unclear whether vector feeding preference or differential susceptibilities of host plants and vectors to phytoplasmas is the primary factor in determining the type of phytoplasma in each of the five host plants.

Several factors may have contributed to the major outbreak of AY disease of 2000 in southwestern Texas. A mild winter (19992000) coupled with an abundant leafhopper population present in this region may have resulted in an increased source of AY phytoplasmas. The primary sources of AY phytoplasmas and phytoplasma-carrying leafhoppers, which were responsible for the infections at the beginning of the growing season of each crop, are unknown. Due to the unusually warm winter, with an average temperature of $65^{\circ} \mathrm{F}\left(\approx 6^{\circ} \mathrm{F}\right.$ above normal), the source of $\mathrm{AY}$ phytoplasma inoculum could be overwintering infected leafhoppers that were already present in this region and continued to reproduce in crops and weeds throughout winter. However, prior to October 1999, there was no noticeable AY infection in crops (e.g., spinach and carrot) that are susceptible to AY phytoplasma. The earliest symptoms were found in carrot in February 2000 (1 to 2 months after planting). It is likely that these AY phytoplasmainfected insects may have migrated from outside the region during the growing season (October 1999 to March 2000) of the crops involved in the AY epidemic. It is more likely that AY phytoplasma-infected leafhoppers migrated into this region during early winter from Mexico, Gulf coastal states, or both. The phytoplasma-carrying leafhoppers, if in abundance, migrating from a more southerly latitude or elsewhere, may play a more important role in intermittent outbreaks of AY in the southwestern region of Texas. A severe drought from October to December 1999 was another factor that may have contributed to the influx of leaf-
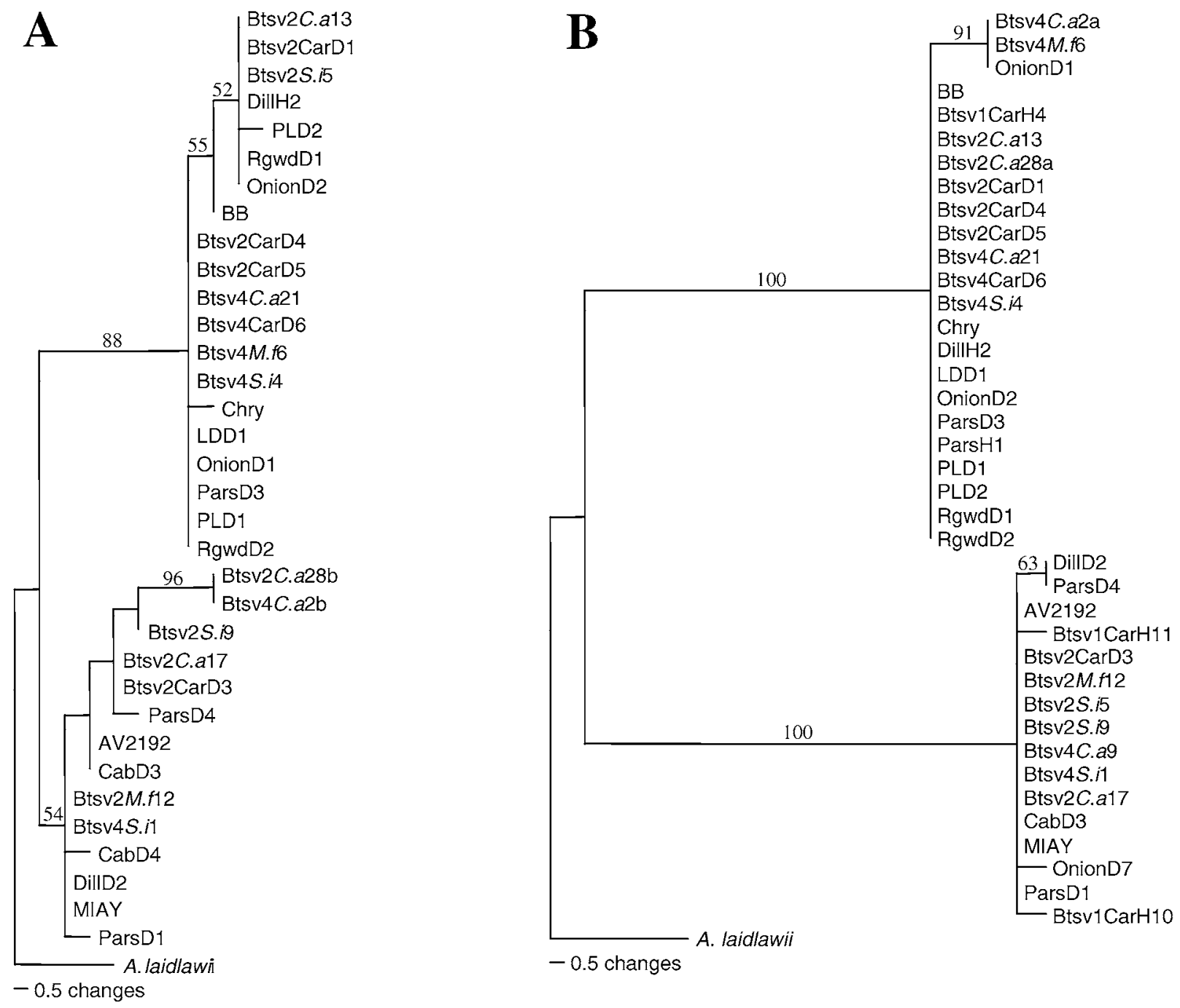

Fig. 5. A, Phylogenetic tree constructed by parsimony analysis of near full length $16 \mathrm{~S}$ rDNA sequences from vegetable crops: carrot (Btsv2CarD1, Btsv2CarD3, Btsv3CarD4, Btsv2CarD5, and Btsv4CarD6), cabbage (CabD3 and CabD4), onion (D1 and D2 ), parsley (ParsD1, ParsD3, and ParsD4), and dill (D2 and H2); weeds: prickly lettuce (PLD1 and PLD2), lazy daisy (LDD1), and false ragweed (RgwdD1 and RgwdD2); insect vectors: Macrosteles fascifrons (Btsv2M.f.12 and Btsv4M.f.6,), Scaphytopius irroratus (Btsv4S.i.1, Btsv4S.i.4, Btsv2S.i.5, and Btsv2S.i.9), and Ceratagallia abrupta (Btsv4C.a.2, Btsv2C.a.13, Btsv2C.a.17, Btsv4C.a.21, and Btsv2C.a.28); and reference strains: BB (16SrI-A), Chry (16SrI-A), MIAY (16SrI-B), and AV2192 (16SrI-B), employing Acholeplasma laidlawii as the outgroup. Bootstrap values are shown on branches. B, Phylogenetic tree constructed by parsimony analysis of ribosomal protein operon sequences from vegetable crops: carrot (Btsv1CarH4, Btsv1CarH10, Btsv1CarH11, Btsv2CarD1, Btsv2CarD3, Btsv2CarD4, Btsv2CarD5, and Btsv4CarD6), cabbage (CabD3), onion (D1, D2, D7), parsley (ParsH1, ParsD1, ParsD3, and ParsD4), and dill (D2 and H2); weeds: prickly lettuce (PLD1 and PLD2), lazy daisy (LDD1), and false ragweed (RgwdD1 and RgwdD2); insect vectors: M. fascifrons (Btsv2M.f.12 and Btsv4M.f.6), S. irroratus (Btsv4S.i.1, Btsv4S.i.4, Btsv2S.i.5, and Btsv2S.i.9), and C. abrupta (Btsv4C.a.2a, Btsv4C.a.2b, Btsv4C.a.9, Btsv2C.a.13, Btsv2C.a.17, Btsv4C.a.21, Btsv2C.a.28a, and Btsv2C.a.28b); and reference strains: BB (16SrI-A[rp-A]), Chry (16SrI-A[rp-A]), MIAY (16SrI-B[rp-B]), and AV2192 (16SrI-B[rp-B]), employing Acholeplasma laidlawii as the outgroup. Bootstrap values are shown on branches. 


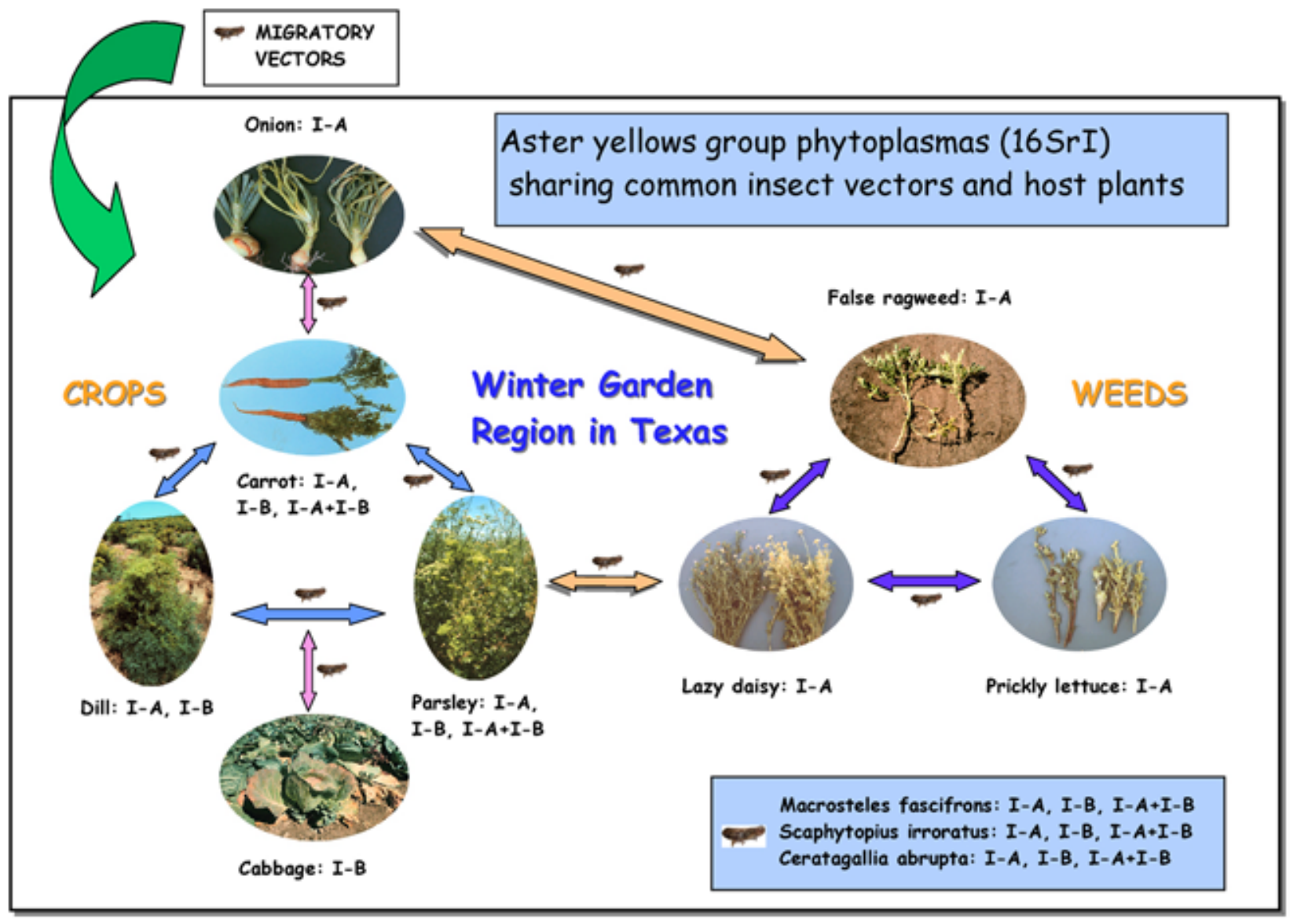

Fig. 6. Proposed ecological model illustrating the three-way interaction among the vegetable crops, weeds, phytoplasmas, and insect vectors involved in the 2000 outbreak of aster yellows in the Winter Garden region of Texas. An epidemiological survey indicated that carrot, dill, parsley, and all three potential vectors were infected by both 16SrI-A and 16 SrI-B phytoplasmas, whereas onion, cabbage, and three species of weeds were infected predominantly or exclusively by either 16SrI-A or 16SrI-B phytoplasma. The three predominant vectors present in this region are polyphagous and carried (or were infected by) $16 \mathrm{SrI}-\mathrm{A}$, 16SrI-B, or both phytoplasmas, although Macrosteles fascifrons primarily carried 16SrI-A phytoplasma strains. Individual insects that carried both 16SrI-A and 16SrI-B were very common among populations of the vectors Scaphytopius irroratus and Ceratagallia abrupta collected from several representative fields. As a result, mixed infections were common in carrot, dill, and parsley. The ecological constrains of 16SrI-A or 16SrI-B phytoplasma strains in these plant hosts appeared to result from the three-way phytoplasma-vectors-host plant interactions. Three major contributing factors: constituent populations of various vectors in a given time period, insect feeding preferences of host plants, and differential susceptibilities of host plants and insects to phytoplasmas, all play an important role in determining the final constituent of phytoplasma type or types in each individual plant or a given crop. Sequence and phylogenetic analyses based on both 16S rRNA and ribosomal protein genes revealed that both subgroup A and subgroup B phytoplasmas were highly homogenous, indicating that the source of phytoplasma strains most likely originated from the same common pools. The phytoplasma-carrying leafhoppers migrating from southerly latitude or elsewhere may present a primary source of aster yellows phytoplasmas responsible for the epidemic.

hoppers from the vicinity of the region. Unlike other surrounding areas, the drought had little effect in the Winter Garden region because crop production in this region is mainly dependent upon irrigation.

Since this study was completed, leafhoppers and AY disease have been unnoticeable in the crops of 2001 in the Winter Garden region (M. C. Black and N. Troxclair, personal communication). This underscores the idea that the influx of migrating leafhoppers may play the major role in the outbreak of AY disease. Seasonal monitoring of leafhopper populations should facilitate the prediction of potential future outbreaks. Molecular methods employed in this study proved to be useful in accurately determining the causal phytoplasmas of diseases associated with carrot and other crops and weeds, and in search of potential insect vectors that transmit the diseases.

\section{ACKNOWLEDGMENTS}

We thank S. H. McKamey, USDA-ARS Systematic Entomology Laboratory, c/o the National Museum of Natural History, Smithsonian Institution, Washington, DC, for identification of insect vectors.

\section{LITERATURE CITED}

1. Bianco, P. A., Davis, R. E., Prince, J. P., Lee, I.-M., Gundersen, D. E., Fortusini, A., and Belli, G. 1993. Double and single infections by aster yellows and elm yellows MLOs in grapevines with symptoms characteristic of flavescence doree. Riv. Patol. Veg. 3:69-82.

2. Deng, S., and Hiruki, C. 1991. Amplification of 16S rRNA genes from culturable and non-culturable mollicutes. J. Microbiol. Methods 14:5361.

3. Green, M. J., Thompson, D. A., and MacKenzie, D. J. 1999. Easy and efficient DNA extraction from woody plants for the detection of phytoplasmas by polymerase chain reaction. Plant Dis. 83:482-485.

4. Gundersen, D. E., and Lee, I.-M. 1996. Ultrasensitive detection of phytoplasmas by nested-PCR assays using two universal primer pairs. Phytopathol. Mediterr. 35:114-151.

5. Gundersen, D. E., Lee, I.-M., Schaff, D. A., Harrison, N. A., Chang, C. J., Davis, R. E., and Kingsbary, D. T. 1996. Genomic diversity and differentiation among phytoplasma strains in 16S rRNA group I (aster yellows and related phytoplasmas) and III (X-disease and related phytoplasmas). Int. J. Syst. Bacteriol. 46:64-75.

6. Ivanoff, S. S., and Ewart, W. H. 1944. Aster yellows on vegetable crops and weeds in the Winter Garden region of Texas. Plant Dis. Rep. 28:972-977.

7. Kunkel, L. O. 1926. Studies on aster yellows. Am. J. Bot. 23:646-705.

8. Kunkel, L. O. 1932. Celery yellows of California not identical with the aster yellows of New York. Contrib. Boyce Thompson Inst. 4:405-414. 
9. Lee, I.-M., Dane, R. A., and Black, M. C. 2001. First report of a member of aster yellows phytoplasma group and of clover proliferation phytoplasma group associated with onion in Texas. Plant Dis. 85:448.

10. Lee, I.-M., Dane, R. A., Black, M. C., and Troxclair, N. 2001. First report of an aster yellows phytoplasma associated with cabbage in southern Texas. Plant Dis. 85:447.

11. Lee, I.-M., Dane, R. A., Black, M. C., and Troxclair, N. 2001. Epidemiology of aster yellows diseases in various crops in Texas. (Abstr.) Phytopathology 91(suppl.):S54.

12. Lee, I.-M., and Davis, R. E. 2001. Aster Yellows. Pages 60-63 in: Encyclopedia of Plant Pathology. O. C. Maloy and T. D. Murray, eds. John Wiley \& Sons, New York.

13. Lee, I.-M., Davis, R. E., Chen, T.-A., Chiykowski, L. N., Fletcher, J., Hiruki, C., and Schaff, D. A. 1992. A genotype-based system for identification and classification of mycoplasmalike organisms (MLOs) in the aster yellows MLO strain cluster. Phytopathology 82:977-986.

14. Lee, I.-M., Davis, R. E., and Gundersen-Rindal, D. E. 2000. Phytoplasma: Phytopathogenic mollicutes. Annu. Rev. Microbiol. 54:221-255.

15. Lee, I.-M., Gundersen, D. E., Hammond, R. W., and Davis, R. E. 1993. Use of mycoplasmalike organism (MLO) group-specific oligonucleotide primers for nested-PCR assays to detect mixed-MLO infections in a single host plant. Phytopathology 84:559-566.

16. Lee, I.-M., Gundersen-Rindal, D. E., and Bertaccini, A. 1998. Phytoplasma: Ecology and genomic diversity. Phytopathology 88:13591366.

17. Lee, I.-M., Gundersen-Rindal, D. E., Davis, R. E., and Bartoszyk, I. M. 1998. Revised classification scheme of phytoplasmas based on RFLP analyses of 16SrRNA and ribosomal protein gene sequences. Int. J. Syst. Bacteriol. 48:1153-1169.

18. Lim, P. O., and Sears, B. B. 1992. Evolutionary relationships of a plantpathogenic mycoplasmalike organism and Acholeplasma laidlawii deduced from two ribosomal protein gene sequences. J. Bacteriol. 174: 2606-2611.

19. Marcone, C., Lee, I.-M., Davis, R. E., Ragozzino, A., and Seemüller, E. 2000. Classification of aster yellows-group phytoplasmas based on combined analyses of rRNA and tuf gene sequences. Int. J. Syst. Evol. Microbiol. 50:1703-1713.

20. McCoy, R. E., Caudwell, A., Chang, C. J., Chen, T.-A., Chiykowski, L. N., Cousin, M. T., Dale, J. L., deLeeuw, G. T. N., Golino, D. A., Hackett, K. J., Kirkpatrick, B. C., Marwitz, R., Petzold, H., Sinha, R. H., Sugiura, M., Whitcomb, R. F., Yang, I. L., Zhu, B. M., and Seemuller, E. 1989. Plant diseases associated with mycoplasmalike organisms. Pages 545560 in: The Mycoplasmas, vol. 5. R. F. Whitcomb and J. G. Tully, eds. Academic Press, New York.

21. Schneider, B., Seemüller, E., Smart, C. D., and Kirkpatrick, B. C. 1995. Phylogenetic classification of plant pathogenic mycoplasmalike organisms or phytoplasmas. Pages 369-380 in: Molecular and Diagnostic Procedures in Mycoplasmology. I. R. Razin and J. G. Tully, eds. Academic Press, San Diego.

22. Seemüller, E., Marcone, C., Lauer, U., Ragozzino, A., and Göschl, M. 1998. Current status of molecular classification of the phytoplasmas. J. Plant Pathol. 80:3-26.

23. Tsai, J. H. 1979. Vector transmission of mycoplasmal agents of plant diseases. Pages 265-307 in: The Mycoplasmas, vol. 3. R. E. Whitcomb and J. G. Tully, eds. Academic Press, New York. 